\title{
Land Use in the Rural-Urban Interface: Subdivision Design 1
}

FOR 213

Lauren McDonell, Martha C. Monroe, and Jay Tomlinson²

\section{Introduction}

As urban populations grow and more people choose to be close to nature, development inevitably creeps beyond city limits and into rural lands. This new development occurs on a landscape that provides goods and services for our communities, from recreation and beauty, to food and fiber, and to clean air and wildlife habitat: the rural-urban interface. How new neighborhoods in suburban and interface areas are designed can influence residents' quality of life, transportation options, and the health of natural resources in these communities. A growing trend features progressive and neo-traditional subdivision designs that are creating attractive, walkable neighborhoods that encourage social interaction and help conserve natural areas. By becoming aware of these new options and selecting the opportunities that are appropriate for their area, citizens can help influence their local growth management and development plans.

\section{The Conventional Approach}

Residential subdivisions typically consist of low-density, single-family residential development, characterized by a lack of connectivity. In this context, connectivity refers to the presence of easily navigated transportation networks within and between neighborhoods. Wide roads, few sidewalks, and frequent cul-de-sacs, (which reduce connectivity, increase distance to destinations, and contribute to heavier traffic along collector roads), are also common features of conventional large subdivision development. Single-family houses are often developed with large lot sizes (one to four houses per acre), providing lot-scale private open space at the expense of shared open space available to all residents.

The suburbs are enormously popular. In fact, in the United States, suburban sprawl is the standard pattern of growth (Duany et al. 2000). Sprawl has a variety of definitions, but in land-use language, it tends to refer to auto-dependent development for housing and commerce that is spread outside of urban centers, along highways and in rural areas (Smart

1. This document is FOR 213, one of a series of the School of Forest Resources and Conservation Department, Florida Cooperative Extension Service, Institute of Food and Agricultural Sciences, University of Florida. Original publication date April 2009. Visit the EDIS Web Site at http://edis.ifas.ufl.edu.

2. Lauren McDonell, Global Warming Project Coordinator, Aspen Colorado; Martha C. Monroe, Professor, School of Forest Resources and Conservation, Institute of Food and Agricultural Sciences, University of Florida, Gainesville, FL 32611; Jay Tomlinson, North Carolina State University, College of Design.

The Institute of Food and Agricultural Sciences (IFAS) is an Equal Opportunity Institution authorized to provide research, educational information and other services only to individuals and institutions that function with non-discrimination with respect to race, creed, color, religion, age, disability, sex, sexual orientation, marital status, national origin, political opinions or affiliations. U.S. Department of Agriculture, Cooperative Extension Service, University of Florida, IFAS, Florida A. \& M. University Cooperative Extension Program, and Boards of County Commissioners Cooperating. Millie Ferrer, Interim Dean 
Growth Vermont 2008). This type of development

leads to a variety of problems in the built environment. There is usually little diversity of income and other socioeconomic factors within residential subdivisions, thus leading to class segregation. Their lack of connectivity makes biking and walking difficult and requires the use of automobiles. The lack of a mix of land uses means that individuals must travel long distances to meet their basic needs, such as jobs, shopping, and professional and government services. Often these developments are not only isolated from other types of land uses but also from one another, forcing individuals to drive to visit their friends.

New subdivisions are most commonly placed on previously undeveloped land known as greenfield sites. This land is often located either on the fringe of a community or, in some cases, well beyond any existing development. Such development involves the conversion of agricultural, forested, or other open space to a more intensively developed use. New subdivisions built on greenfield sites usually involve less expensive land and less opposition from neighbors than infill development, and greater overall flexibility. Greenfields may also provide developers with some taxpayer-supported new infrastructure and may involve more lenient zoning standards. In short, developers often prefer to build on greenfield sites because the risks are lower. Such sites are easier to develop because they present fewer regulatory, financial, and construction obstacles than infill sites or property that is adjacent to a developed area. In most cases, additional development, such as wider roads, grocery stores, and services spring up on major roads leading to these large, remote subdivisions, but not close enough for residents to walk to.

\section{New Approaches}

Smart growth promotes alternatives to the conventional subdivision approach. Many new subdivisions are being created as "traditional neighborhood developments," or new urbanist communities. These developments mimic urban neighborhood design principles popular in the first half of the twentieth century and typically feature a mix of housing types, street front porches, rear loaded garages, narrow gridded streets, sidewalks, and an integration of uses such as homes, shops, and open space (see Tioga and Seaside, discussed later in this publication).

Another increasingly popular alternative to today's typical subdivisions is the conservation subdivision. Conservation subdivisions employ smart growth principles, creating dense clusters of homes and leaving undeveloped greenspace for agriculture, conservation, and community use. The conservation subdivision considers both the quantity and quality of the preserved land. Generally 40 to 60 percent of a development site is set aside in primary or secondary conservation areas (Myszewski 2005). Homes are built on smaller lots than in a conventional subdivision and are situated to provide the greatest view of the preserved open space. Conservation subdivisions, such as Aylesbury Plantation, planned for Jefferson County, Florida, can also be designed to make the best possible use of existing infrastructure. Placing residential development within a natural resource context means that land-use planning decisions will be made in accordance with a cohesive plan for the whole regional landscape rather than considered individually, project by project. New developments in Flower Mound, Texas, for example, are designed to reduce construction floodplains and to link adjoining parcels for linear recreation areas. Developers who submit plans for a conservation development must work closely with planning officials to ensure that natural areas on the site are preserved (Austin and Kaplan 2003). Natural resource professionals could assist planners and developers in this process.

Smart growth seeks to integrate rather than segregate employment, residences, and shopping. The goal is to encourage behaviors and activities such as walking and bicycling for errands and chores, thus creating fewer and shorter trips to jobs and for personal needs. In addition, infrastructure and construction methods can use, for example, shorter utility lines and more efficient building orientation to maximize solar energy gain, condense stormwater drainage, and decrease other negative environmental effects. Smart growth seeks to accommodate growth sensibly by encouraging a mix of higher densities in or immediately adjacent to already built-up areas, to reduce the amount of sprawl while at the same time 
conserving greenspace for environmental, health, and aesthetic reasons.

Supporters of large, single-use subdivisions often claim that their projects keep housing prices low. However, these claims often ignore some of the hidden costs of low-density development, both private and public, such as traffic, increased fuel costs, the expenses of utility extensions and infrastructure such as roads, and the costs of added pollution. Thus, an analysis of large subdivision developments should include not only the costs and benefits of the specific project, but also its wider effect on the rest of the community. Smart growth encourages communities to examine all aspects of a development before it occurs to ensure that it is in the best interests of the entire community.

\section{Examples from Florida}

There are many developments in Florida that feature traditional neighborhood designs, new urbanist designs, and conservation subdivision principles. A number of EDIS fact sheets provide complementary information about housing developments and land-use planning and can be found at http://edis.ifas.ufl.edu/. Following are some examples of communities that demonstrate innovative design ideas.

\section{Madera}

Madera is an 88-home low-impact community in Alachua County that sits on a 44-acre site. With technical guidance from the Program for Resource Efficient Communities at the University of Florida, builders, architects, and others worked to make the subdivision one in which humans and nature can coexist. Durable and recyclable construction materials were used to build the homes and yards are landscaped with native and drought-tolerant plants (UF News 2005). All homes are ENERGY STAR®-Qualified New Homes (i.e., designed to be at least 15 percent more efficient than comparable code minimum designs) and certified by the Florida Green Building Coalition.

Low impact development (or LID) is a component of green development focused on protecting water quality and quantity through stormwater design more akin to the natural hydrology of the site. Beyond the Florida-Friendly landscaping, other LID features in Madera include lot-level rain gardens, narrow uncurbed roads with vegetated swales, reduced irrigable areas at both the lot level and the community level, and preservation of extensive existing vegetation through careful and limited lot clearing and construction material staging. These practices allow rainfall to be intercepted by the preserved trees as well as infiltrated into the soil in a more natural distribution pattern than the centralized retention/detention ponds common in conventional development. Additionally, the water efficiency features have contributed to a community average household annual water use of approximately 60,000 gallons per year, which is less than half of the average use (approximately 130,000 gallons per year) for homes in a conventional community located across the street.

\section{Harmony}

Harmony is another community developed with direction from the University of Florida's Program for Resource Efficient Communities. The winner of multiple awards for environmental stewardship, the development is set on 11,000 acres in Osceola County, with more than 7,700 acres conserved for wildlife habitat, greenspace, wetlands, lakes, and recreation areas. In 2008, the Harmony community achieved certification as a Florida Green Building Coalition Green Development. The development also features a golf course, designed to wrap around existing wetland areas. All homes and townhouses (from 1,305 to 6,216 ft2) are built to be ENERGY STAR®-Qualified New Homes, featuring energy-efficient appliances, high-quality windows, tightly sealed duct systems and high-performance water heating equipment (http://www.harmonyfl.com/) (Figure 1). The development features a town square with schools, shops, and restaurants within walking distance. There are also educational kiosks throughout the community, providing seasonally relevant messages about environmental issues related to the community (http://www.harmonyfl.com/lih/index.htm). 


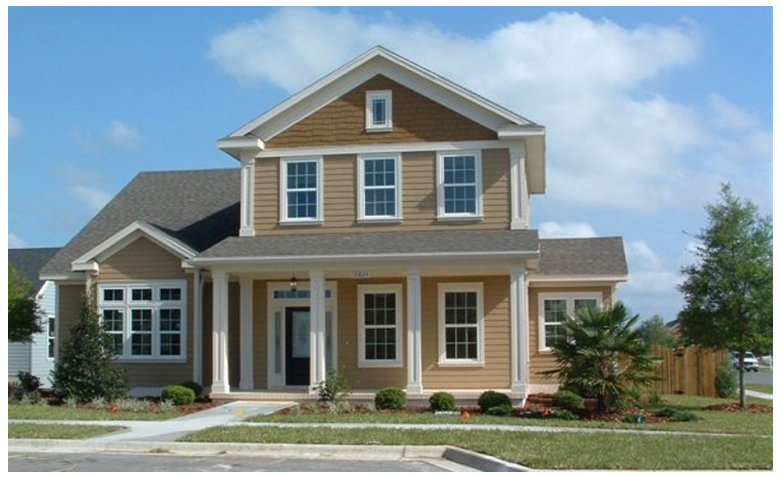

Figure 1. The Town of Tioga won the 2001 national Best Smart Growth Community gold award for its innovative design. Photo by Greta Rice.

\section{Town of Tioga}

The Town of Tioga is a traditional neighborhood design development built on a 500-acre parcel in Alachua County. Designed with narrow streets, tree-lined sidewalks, and bike lanes, twenty percent of the development is reserved greenspace and the Town's center includes shops, office space, and restaurants. Houses are built with old-fashioned front porches and back-alley parking and are set close to sidewalks, encouraging friendly interactions among neighbors. Weekly farmers' markets provide residents easy access to locally grown produce. Granted the 2001 national "Best Smart Growth Community" gold award, the Town of Tioga exemplifies many smart growth principles (http://www.townoftioga.com/). While incorporating retail businesses into the development likely reduces the need for residents to drive, Tioga is approximately a 20-minute drive from the closest urban area, Gainesville.

\section{Casa San Juan Bosco}

Once completed, Casa San Juan Bosco, in Desoto County, will be a Florida Green Building Coalition-certified affordable housing community for more than 700 local farm workers. In 2004, Hurricane Charley left more than 60 percent of the area's seasonal and migrant farm workers without housing (Miguel 2008). Casa San Juan Bosco, set on 86 acres, will feature energy-efficient, fire-resistant pre-fabricated houses, designed to withstand hurricane-force winds. Rent for two- to four-bedroom houses will range from approximately $\$ 450$ to $\$ 650$ per month. Plans include the conservation of about half of the land for wetlands, parks, and ponds. Designed to provide a sense of community, the development will include an 8,000 square-foot Energy $\operatorname{Star}^{\odot}{ }^{-}$-certified community center where after-school activities, immigration services, and English and health classes will be held. The community is located less than two miles from the town of Arcadia and will also have its own public transportation (Miguel 2008).

\section{Aylesbury Plantation}

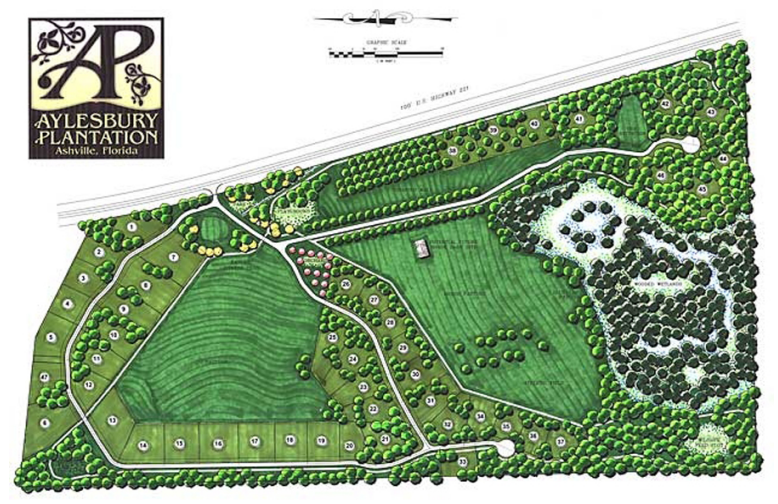

Figure 2. Once completed, Aylesbury Plantation will offer residents more than 70 acres of preserved greenspace. Image courtesy of Aylesbury Plantation.

Still under development, Aylesbury Plantation, located in Jefferson County about 35 miles east of Tallahassee near the Georgia-Florida state line, is a rural subdivision designed to promote land conservation and a country atmosphere for its residents. The development consists of 47 home lots on 111 acres, with 73 acres in preserved open space (Figure 2). Once completed, the development will include more than two miles of nature trails running through pastures and forests and will feature a wildlife observation tower, a horse barn and pasture, and a community vegetable garden and fruit orchard. The Aylesbury Plantation Web site boasts that residents will enjoy low maintenance yards while benefiting from the beauty and shared ownership of expansive greenspace, maintained by the homeowners' association. The site also points out that research has shown that homes in conservation developments tend to appreciate more rapidly than houses in traditional neighborhoods. Plans for Aylesbury Plantation have helped inspire new county ordinances encouraging conservation development practices by granting density increases to developers that use conservation 
development principles

(http://www.aylesburyplantation.com/).

\section{Roosevelt Village and Gateway Centre}

Grady Pridgen, Inc. is an environmentally responsible development company. The company specializes in sustainable, mixed-use developments that use green building practices and products. Grady Pridgen, Inc. developments feature low impact design, zero-waste recycling, and water conservation features like low-flow faucets and toilets. One of the company's developments, Roosevelt Village in Hillsborough County, is walkable, close to shopping and restaurants, and provides residents easy access to mass transit. Gateway Centre, another of Grady Pridgen, Inc.'s developments, is a 700-acre community that features office space and residential units and is also mass transit oriented and walkable. In an effort to address climate change concerns, the company is supporting the establishment of a Zero Carbon Mandate in the state of Florida by 2017. To offset its own carbon, the company plans to incorporate green roofs (roofs planted with vegetation to reduce heat absorption), increased recycling, renewable energy, electric-powered mass transit, and other green practices into its developments (http://www.gradypridgen.com/).

\section{Seaside ${ }^{\circledR}$}

Seaside is a master-planned community in Walton County that some believe exemplifies a successful new urbanist community. The community was founded in 1979 and designed by legendary new-urbanist architectural firm, Duany and Plater-Zyberk. With wood-frame cottages, front porches, and white picket fences, the beach community is designed to have a timeless, small-town feel. The community includes a neighborhood charter school, a chapel, shops, restaurants, banks, art galleries, and a performing arts theatre.

Thanks to the community's responsible management, Seaside's half-mile stretch of white sand beach has been designated a Blue Wave Beach from the Clean Beach Council. The town is also home to Seaside Institute, a non-profit organization dedicated to promoting smart growth, new urbanism, and other innovative community design principles (http://www.seasidefl.com/).

\section{Brytan}

The vision for Brytan, a new-urbanist, mixed-use community in Alachua County, was created during a week-long "charrette" (a charrette is a community meeting used to facilitate planning and design decisions). Like Seaside, Brytan was designed with guidance from Duany Plater-Zyberk and Company. The development features 700 residential lots, 300,000 square feet of commercial space, and parks, shops, restaurants, and nature trails. In addition, all of Brytan's homes and the development itself will be LEED $^{\mathrm{TM}}$ (Leadership in Energy and Environmental Design) silver certified by the U.S. Green Building Council's LEED ${ }^{\mathrm{TM}}$, meeting standards that conserve energy, reduce urban sprawl, and promote the use of alternative transportation (Figure 3). The development also features management plans to relocate and conserve threatened and endangered plants and animals on the property, including the endangered poppy mallow, eastern indigo snake, gopher tortoise, and southeastern American kestrel. Hazel's Garden, Brytan's environmental educational park, provides residents and visitors with information about these species and other environmental issues (http://brytan.com/).

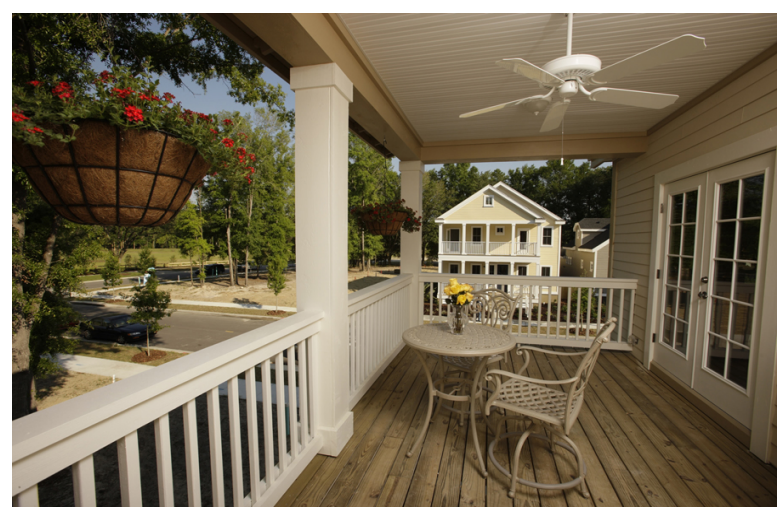

Figure 3. Homes in Brytan and the community as a whole are LEED-silver-certified. Photo by David Johnston.

\section{Summary}

The design and development of individual neighborhoods in suburban and interface areas strongly influence the surrounding built and natural communities. Conventional subdivision design practices tend to create low-density development that lacks shared greenspace, walkability, and 
connectivity within and between neighborhoods.

Developers and residents are exploring new ways of living that provide social, economic, and environmental benefits. These developments can enhance a community and minimize environmental impacts, rather than the opposite. Smart growth and new-urbanism principles create residential spaces that offer home buyers a good quality of life, a variety of housing choices, and a sense of community, while protecting natural resources and preserving greenspace. Developers are beginning to realize that many home buyers prefer the amenities offered by traditional neighborhood developments and other smart growth designs over typical suburban subdivision designs.

\section{References}

Aylesbury Plantation Web site. 2008. http://www.aylesburyplantation.com/about.htm. (Accessed September 18, 2008).

Austin, M. E. and R. Kaplan. 2003. "Resident Involvement in Natural Resources Management: Open Space Conservation Design in Practice." Local Government 8(2): 141-153.

Brytan Web site. 2008. http://www.brytan.com/. (Accessed October 2, 2008).

Duany, A.; E. Plater-Zyberk; and J. Speck. 2000. Suburban Nation. New York: North Point Press, A Division of Farrar, Straus and Giroux.

Grady Pridgen, Inc. Web site. 2008. http://www.gradypridgen.com/. (Accessed October 2, 2008).

Harmony Florida Web site. 2008. http://www.harmonyfl.com/index.html. (Accessed September 18, 2008).

Myszewski, Margaret. Education Program Specialist with the University of Georgia, Carl Vinson Institute. E-mail correspondence, May 15, 2005.

Miguel, Tracy X. Naples Daily News. Naples.com. February 14, 2008. "A model development? Collier leaders travel to Arcadia to check out new project." http://www.naplesnews.com/news/2008/Feb/14/ model-development-collier-leaders-travelarcadia-c/. (Accessed September 18, 2008).

Seaside ${ }^{\circledR}$ Web site. 2008. http://www.seasidefl.com/default.asp. (Accessed September 18, 2008).

Smart Growth Vermont Web site. 2008. "What is sprawl?"

http://www.smartgrowthvermont.org/learn/sprawl/ (Accessed December 18, 2008).

Town of Tioga Web site. 2008. http://www.townoftioga.com/community.html. (Accessed September 18, 2008).

University of Florida, Institute for Food and Agricultural Sciences Cooperative Extension, Living in Harmony Web site. 2008. http://www.wec.ufl.edu/extension/gc/harmony/. (Accessed September 18, 2008).

UF News. 2005. http://news.ufl.edu/2005/10/04/green-buildings/. (Accessed September 18, 2008). 